\title{
Virulence Markers and Antimicrobial Susceptibility of Bacteria of the Bacteroides fragilis Group Isolated from Stool of Children with Diarrhea in São Paulo, Brazil
}

\author{
Viviane Nakano $^{++}$, Mario J Avila-Campos ${ }^{+}$
}

\author{
Laboratório de Anaeróbios, Departamento de Microbiologia, Instituto de Ciências Biomédicas, Universidade de São Paulo, \\ Av. Prof. Lineu Prestes 1524, 05508-900 São Paulo, SP, Brasil
}

\begin{abstract}
Bacteroides fragilis has been isolated from several human and non-human monomicrobial and mixed infections. In this study, some virulence markers and the antimicrobial susceptibility of bacteria of the B. fragilis group isolated from children's stools were evaluated. All the 64 isolates showed the following characteristics: capsulated, $\beta$ hemolytic, hydrophilic, and serum-resistant. Only, 24 (37.5\%) strains were resistant at $60^{\circ} \mathrm{C}$, for $30 \mathrm{~min}$, and among them, $12(18.75 \%)$ were resistant at $60^{\circ} \mathrm{C}$, for $60 \mathrm{~min}$. Also, none strain was resistant at $100^{\circ} \mathrm{C}$. Four strains were able to hemagglutinate erythrocytes and D-mannose, D-galactose, D-arabinose, and D-xylose inhibited hemagglutination in $2 \mathrm{~B}$. fragilis strains ( $p 76 a, p 76 b)$. The hemagglutination in the strain $\mathrm{B}$. uniformis $p 3-2$ was inhibited by $D$-xylose and D-galactose. The bft gene detection and the enterotoxin production were observed only in $13 \mathrm{EF}$ enterotoxigenic species. Fragilysin activity was confirmed on HT-29 cells. The antimicrobial determination confirmed that both imipenem and metronidazole were efficient against $\mathrm{B}$. fragilis species; all the strains were resistant to lead and nickel. Plasmids of 2.9, 4.4, 4.8, and $8.9 \mathrm{~kb}$ were observed in 6 tested strains. These results show the values of the species identification from clinical infections, as well as of the periodic evaluation of the resistance patterns of the $\mathrm{B}$. fragilis group at Brazilian medical institutions.
\end{abstract}

Key words: Bacteroides fragilis - enterotoxigenic Bacteroides fragilis - pathogenesis - antimicrobial resistance - plasmid

Species of the genus Bacteroides are important constituents of both human and animal intestinal microbiota, achieving approximately $30 \%$ of the total of organisms cultured from feces (Soki et al. 1999).

Bacteroides fragilis is considered to be the most virulent species in this genus due to its virulence factors and its predominance in monomicrobial and mixed infections such as brain, lung, intra-abdominal and intra-pelvic abscesses, peritonitis, and sepsis. Some virulence factors were noticed in B. fragilis such as adherence, hemagglutination, polysaccharide capsule, fimbriae, as well as antibiotic and metal ion resistances (Gorbach \& Bartlett 1974, Duerden 1980).

B. fragilis also produces an enterotoxin (ETBF) that causes diarrhea in animals and it has been associated with diarrhea in human beings (Myers et al. 1984). This extracellular toxin has been characterized as a heat-labile zincmetalloprotease of approximately $20 \mathrm{kDa}$ and it resides as a pro-toxin in the periplasmic space (Moncrief et al. 1995). The $b f t$ chromosomal gene, which has been isolated and sequenced, encodes the toxin named fragilysin. It has been observed a toxin activity against tight junction proteins,

Financial support: Fundação de Amparo à Pesquisa do Estado de São Paulo, proc. 02/02680-4

${ }^{+}$Corresponding author. Fax: +55-11-3091.7354. E-mail: mariojac@usp.br

${ }^{++}$Fapesp fellowship, proc. 02/02679-6

Received 15 December 2003

Accepted 30 April 2004 disrupting the intestinal epithelial barrier and causing morphologic alterations such as loss of cell-to-cell attachment, rounding, apparent swelling, and pyknosis. Moreover, this fragilysin produces the hydrolysis of gelatin, actin, azocoll, tropomosin, and fibrinogen (Koshy et al. 1996, Franco et al. 1997, Kato et al. 2000).

In the present study, bacteria of the $B$. fragilis group isolated from stool samples of children with diarrhea were evaluated to detect putative virulence factors in vitro such as capsule, temperature and serum resistance, hemolytic activity, hemagglutination, hydrophobicity, antibiotic and metal susceptibility, and plasmid detection; the presence of the bft gene and the fragilysin production were also detected.

\section{MATERIALS AND METHODS}

Bacterial strains - Clinical isolates were obtained from diarrhea stool samples collected from April to December 2000 in 2 child hospitals of São Paulo, Brazil (Hospital Menino Jesus and Instituto da Criança do Hospital das Clínicas). A total of 64 strains of the $B$. fragilis group were isolated from the intestinal microbiota of 15 children with diarrhea (ranges from 2 months old to 6 years old). Bacteria were isolated and identified at the Anaerobe Laboratory, Department of Microbiology, University of São Paulo. Two positive enterotoxigenic $B$. fragilis ATCC 43858 and GAI 97124, kindly provided by Dr Annalisa Pantosti (Laboratory of Bacteriology and Medical Mycology, Institute Superiore di Sanità, Rome, Italy) and by Dr Naoki Kato (Institute of Anaerobic Bacteriology, Gifu University School of Medicine, Gifu, Japan), respectively, were used as positive control in the enterotoxin production assay. Strains were stored in $10 \%$ skim milk at $-80^{\circ} \mathrm{C}$. The Ethic 
Commission of the hospitals and of the Instituto de Ciências Biomédicas, USP (Parecer 158/CEP) approved this study.

Capsule detection - Capsules were detected by using a Hiss stain with modifications (Namavar et al. 1991). Each isolate was anaerobically grown in peptone-yeast extract (PY) with $1 \%$ glucose. A drop of 24-h-bacterial-suspension was deposited on a microscope slide, and it was fixed with methyl alcohol (100\%), for $1 \mathrm{~min}$. Then, it was covered with crystal violet and heated until vapor emission. Each slide was washed with $20 \%$ (w/v) of copper sulfate and allowed to air-dry. Capsule was identified under light microscopy $(100 X)$ through verification of a clear area around the bacteria.

Temperature resistance - Strains were grown in brain heart infusion broth (BHI, Oxoid), supplemented with yeast extract $(0.5 \%)$ in anaerobiosis conditions $\left(90 \% \mathrm{~N}_{2} / 10 \%\right.$ $\mathrm{CO}_{2}$ ), at $37^{\circ} \mathrm{C}$, for $48 \mathrm{~h}$; aliquots of $0.1 \mathrm{ml}$ were inoculated in $5 \mathrm{ml}$ of fresh BHI medium and then incubated in water bath at $60^{\circ} \mathrm{C}$, for $30 \mathrm{~min}$, and afterwards for $1 \mathrm{~h}$, and also at $100^{\circ} \mathrm{C}$, for 1,5 , and $10 \mathrm{~min}$ (Holdeman et al. 1977). After the period of incubation, the tubes were incubated under anaerobiosis, at $37^{\circ} \mathrm{C}$, for $48 \mathrm{~h}$. Bacterial growth was interpreted as a heat-resistance. An inoculated BHI broth, not exposed at heat, was used as control.

Hemolytic activity - The hemolysin production was performed on trypticase soy agar (TSA, Oxoid) enriched with horse blood (5\%) (Avila-Campos 1995). The strains were grown in BHI broth supplemented with yeast extract $(0.5 \%)$ and incubated in anaerobiosis, at $37^{\circ} \mathrm{C}$, for $48 \mathrm{~h}$. Plates were inoculated in duplicate by using a Steer's replicator, with a given final inocula of $c a .10^{5} \mathrm{cfu} / \mathrm{spot}$, and then incubated at $37^{\circ} \mathrm{C}$, for $48 \mathrm{~h}$. The hemolytic activity was identified through the verification of a clear zone around the bacterial growth.

Serum resistance - Serum resistance was tested using human and horse sera (Namavar et al. 1991). Each serum was pooled, and aliquots of $1 \mathrm{ml}$ were stored at $-20^{\circ} \mathrm{C}$. Each strain grew for $24 \mathrm{~h}$ in BHI broth and they were washed once in $0.01 \mathrm{M}$ of phosphate-buffered saline (PBS, $\mathrm{pH} 7.4)$; then $1 \mathrm{ml}\left(1.5 \times 10^{8} \mathrm{cfu} / \mathrm{ml}\right)$ was mixed with $1 \mathrm{ml}$ of human $(100 \%)$ or horse $(100 \%)$ serum, and incubated in anaerobiosis, at $37^{\circ} \mathrm{C}$, during $4 \mathrm{~h}$. Afterwards, $0.1 \mathrm{ml}$ of each mixture was removed and inoculated on blood agar with a Steer's replicator $\left(10^{5} \mathrm{cfu} / \mathrm{spot}\right)$ and incubated in anaerobiosis, at $37^{\circ} \mathrm{C}$, for $48 \mathrm{~h}$, for viable counts. $100 \%$ of inactivated sera $\left(56^{\circ} \mathrm{C}, 30 \mathrm{~min}\right)$ were used as control. A total bacterial inhibition was considered susceptible to serum.

Hemagglutination assays (HA) - Organisms were grown in BHI broth, in anaerobiosis, for $24 \mathrm{~h}$, at $37^{\circ} \mathrm{C}$, then harvested, pellet, and washed $(10,000 \mathrm{~g}, 5 \mathrm{~min}) 3$ times in PBS. The bacterial suspension was adjusted to ca. $1.5 \times 10^{8} \mathrm{cfu} / \mathrm{ml}$ (Vel et al. 1986). Human erythrocytes, collected each week and stored at a concentration of $10 \%$ (v/v), in Alsever's solution, from a 23 year-old man, A Rhpositive donor, were harvested and then washed 3 times $\left(600 \mathrm{~g}, 4^{\circ} \mathrm{C}, 5 \mathrm{~min}\right)$ and finally resuspended at $1 \%$ in PBS. HA was tested qualitatively by mixing $50 \mu 1$ of bacterial suspension with $50 \mu 1$ of erythrocyte suspension in a 96well microtitre plate (V shaped). Two-fold serial dilutions of the bacterial suspension of a final volume of $50 \mu 1 /$ well were performed. Then, $50 \mu 1$ erythrocytes were added to each dilution and the plate was gently shaken, being incubated first at $37^{\circ} \mathrm{C}$, for $1 \mathrm{~h}$, and afterwards at $4^{\circ} \mathrm{C}$, overnight. Hemagglutination activity titers were expressed through the reciprocal of the highest bacterial dilution showing agglutination activity.

Hemagglutination assay inhibition (HAI) - The ability of D-arabinose, D-galactose, D-mannose and D-xylose to inhibit hemagglutination was evaluated. Each carbohydrate was dissolved in $80 \mathrm{mM}$ of PBS and then filtrated ( $0.45 \mathrm{~mm}$, Millipore). To each $9.9 \mathrm{ml}$ of each carbohydrate solution it was added $0.1 \mathrm{ml}$ of washed erythrocytes. The HAI was qualitatively performed by mixing 50 $\mu 1$ of bacterial suspension with $50 \mu 1$ of erythrocytes treated with each carbohydrate suspension. Two-fold serial dilutions of the bacterial suspension of a final volume of 50 $\mu 1 /$ well were performed. Then, $50 \mu 1$ of erythrocytes treated with carbohydrate were added and the plate was gently shaken, incubated $\left(37^{\circ} \mathrm{C}, 1 \mathrm{~h}\right)$, and then at $4^{\circ} \mathrm{C}$, overnight. Erythrocytes treated with sugar and mixed with PBS were used as negative control.

Hydrophobicity $(\mathrm{Hp})$ - The hydrophobicity of the bacterial surface was measured through the interaction with hexadecane (Rosenberg et al. 1981). Strains grown in BHI broth for $24 \mathrm{~h}$, at $37^{\circ} \mathrm{C}$, were washed three times in phosphate-urea-magnesium buffer (PUM) and resuspended to $c a .1 .5 \times 10^{8}$ bacteria/ml. Then, $3 \mathrm{ml}$ of bacterial suspension were mixed with $400 \mu$ l of n-hexadecane (Sigma Chemical Co., US) and incubated at $30^{\circ} \mathrm{C}$, for $10 \mathrm{~min}$. After the vortex and the separation of 2 phases, absorbance $\left(\mathrm{A}_{550 \mathrm{~nm}}\right)$ was determined. Hp values were expressed through the percentage of bacteria recovered in the aqueous phase. Percentage values $>50 \%$ were considered as hydrophilic, and $\mathrm{Hp}<50 \%$ as hydrophobic. These tests were performed in triplicate.

Fragilysin activity - Bacterial supernatants were used. HT-29/C 1 cells were grown in flasks of $25 \mathrm{~cm}^{2}$ with $5 \mathrm{ml}$ of Eagle's medium with glutamine (Gibco), supplemented with penicillin $(100 \mathrm{UI} / \mathrm{ml})$, streptomycin $(100 \mu \mathrm{g} / \mathrm{ml})$, and inactivated fetal bovine serum (15\%); then they were incubated in air plus $5 \% \mathrm{CO}_{2}$, at $37^{\circ} \mathrm{C}$. These cells were distributed $(200 \mu 1 /$ well) into a 96 -microtitration plate (Corning, US), and they were allowed to grow during 2-3 days. Before the assay, the medium was removed and $180 \mu$ l of fresh medium without serum were added to each well, and then $20 \mu \mathrm{l}$ of supernatant were added in each well, in duplicate. The plate was incubated at $37^{\circ} \mathrm{C}$, in air plus $5 \%$ $\mathrm{CO}_{2}$ and then examined after 3-4 h, period in which the typical toxin-induced cytotoxic changes occur (Pantosti et al. 1994).

Fragilysin gene detection (bft) - From 5 to 6 colonies of each strain were suspended in $1 \mathrm{ml}$ of Milli-Q water, being homogenized and boiled for $10 \mathrm{~min}$, and finally centrifuged at $14,000 \mathrm{~g}$, for $10 \mathrm{~min}$. Supernatants were used as templates. The amplification reaction was performed by using a specific primer pair: 5'- GAC GGT GTA TGT GAT TTG TCT GAG AGA - 3' and 5' - ATC CCT AAG ATT TTA TTA TCC CAA GTA-3' (Gibco BRL) (Pantosti et al. 1997). The polymerase chain reaction (PCR) was performed in a final volume of $25 \mu \mathrm{l}$ containing $2.5 \mu \mathrm{l}$ of $10 \mathrm{X}$ PCR buffer 
(Gibco), $1.25 \mu \mathrm{l}$ of $\mathrm{MgCl}_{2}$ (1.5 mM), $1 \mu \mathrm{l}$ of dNTP $(0.2 \mathrm{mM})$ (Gibco), $0.25 \mu$ l of Taq DNA polymerase (0.5 U) (Gibco), 1 $\mu \mathrm{l}$ of each primer $(0.4 \mathrm{mM}), 8 \mu \mathrm{l}$ of Milli Q water and $10 \mu \mathrm{l}$ of DNA. The thermocycler (Perkin Elmer Amp PCR System 2400) was programmed to: 1 cycle of $94^{\circ} \mathrm{C}$ ( $\left.5 \mathrm{~min}\right)$, followed by 35 cycles of $94^{\circ} \mathrm{C}(1 \mathrm{~min}), 52^{\circ} \mathrm{C}(1 \mathrm{~min}), 72^{\circ} \mathrm{C}$ ( $1 \mathrm{~min})$ and 1 cycle of $72^{\circ} \mathrm{C}(5 \mathrm{~min})$. The amplified products were analyzed by $1 \%$ agarose gel electrophoresis, stained with $0.5 \mu \mathrm{g} / \mathrm{ml}$ of ethidium bromide (EtBr) and photographed by using a Kodak Digital Science System DC 120.

Antibiotic and metal susceptibility testing - An agar dilution method by using a Wilkins-Chalgren agar was used as reference (Sutter et al. 1979, Riley \& Mee 1982). The antibiotics used were: amoxicillin, ampicillin, clindamycin, erythromycin, and tetracycline (Luper Ind. Farm. Ltd., SP, Brazil), amoxicillin/clavulanic acid (Smithkline Beecham Ltd., SP, Brazil), cefoxitin and imipenem (Merck, Sharp \& Dohme, SP, Brazil), penicillin G (Prodoti Lab. Farm. Ltd., SP, Brazil), metronidazole (Aventis Farm. Ltd., SP, Brazil). The metals used were: mercuric chloride $\left(\mathrm{HgCl}_{2}\right)$, silver nitrate $\left(\mathrm{AgNO}_{3}\right)$, copper sulfate $\left(\mathrm{CuSO}_{4}\right)$ and nickel sulfate $\left(\mathrm{NiSO}_{4} 6 \mathrm{H}_{2} \mathrm{O}\right)$ (Labsynth Prod. Lab. Ltd., SP, Brazil), cadmium sulfate $\left(3 \mathrm{CdSO}_{4} \cdot 8 \mathrm{H}_{2} \mathrm{O}\right)$ and lead chloride $\left(\mathrm{PbCl}_{2}\right)$ (Vetec Química Fina Ltd., SP, Brazil).

Antibiotic and metal concentrations were ranged from 0.25 to $512 \mu \mathrm{g} / \mathrm{ml}$. Media without antimicrobials were used as control. Bacterial inocula were standardized to $c a .1 .5 \mathrm{x}$ $10^{8} \mathrm{cfu} / \mathrm{ml}$. Each plate was inoculated by using a Steers replicator, with $\mathrm{ca} .1 .5 \times 10^{5} \mathrm{cfu} / \mathrm{spot}$. All the plates were incubated in anaerobiosis, at $37^{\circ} \mathrm{C}$, for $48 \mathrm{~h}$. The minimal inhibitory concentration (MIC) was defined as the lowest concentration of each antimicrobial agent able to inhibit the macroscopic bacterial growth.

Plasmid detection - Plasmid DNA was extracted from all tested strains by using a Concert ${ }^{\mathrm{TM}}$ Rapid Plasmid Miniprep System (Gibco BRL) from all tested strains. The DNA was analyzed by agarose gel electrophoresis. The strain Escherichia coli J53 pACYC 184 was used as a plasmid-positive control.

\section{RESULTS}

A total of 64 species of the $B$. fragilis group were isolated from the intestinal microbiota of 15 children with diarrhea: 26 B. fragilis; 13 enterotoxigenic $B$. fragilis; 8 B. vulgatus; 6 B. uniformis; 6. B. distasonis; and 5 B. ovatus.

All $B$. fragilis presented a capsule and the following characteristics: $\beta$-hemolytic, hydrophilic, and resistant to human or horse serum. Variable data were verified in the temperature resistance and in the hemagglutination assay. Twenty-four $(37.5 \%)$ were resistant at $60^{\circ} \mathrm{C}$, for 30 min and, among them, only $12(18.75 \%)$ were resistant at $60^{\circ} \mathrm{C}$, for $60 \mathrm{~min}$. None strain was resistant at $100^{\circ} \mathrm{C}$ (Table I).

Four strains were able to hemagglutinate erythrocytes, showing HA titers of 8 (B. uniformis p3-2, B. fragilis $\mathrm{p} 3-3$ ) and 2 (B. fragilis p76a, p76b). Carbohydrates D-mannose, D-galactose, D-arabinose, and D-xylose were able to inhibit the hemagglutination of two B. fragilis strains (p76a, p76b). The strain B. uniformis p3-2 was inhibited only by $\mathrm{D}$-xylose and by D-galactose. Moreover, none carbohy-
TABLE I

Temperature resistance and plasmid profile in 64 Bacteroides fragilis strains isolated from children's stool samples

\begin{tabular}{|c|c|c|c|c|c|}
\hline \multirow[b]{2}{*}{ Species } & \multirow[b]{2}{*}{ Strain nr } & \multicolumn{2}{|c|}{ Resistance to $60^{\circ} \mathrm{C}$} & \multicolumn{2}{|c|}{ Plasmid profile } \\
\hline & & $30 \mathrm{~min}$ & $60 \mathrm{~min}$ & Band nr & $\mathrm{kb}$ \\
\hline B. fragilis & 4 & + & + & - & - \\
\hline B. fragilis & 6 & + & - & - & - \\
\hline B. fragilis & 11 & - & - & - & - \\
\hline B. fragilis & 1 & - & - & 1 & 4.4 \\
\hline B. fragilis & 1 & - & - & 2 & $2.9,4.4$ \\
\hline ETBF & 3 & + & + & - & - \\
\hline ETBF & 7 & - & - & - & - \\
\hline ETBF & 3 & - & - & 1 & 4.4 \\
\hline B. distasonis & 1 & + & + & - & - \\
\hline B. distasonis & 4 & + & - & - & - \\
\hline B. distasonis & 1 & - & - & - & - \\
\hline B.ovatus & 1 & + & - & - & - \\
\hline B. ovatus & 4 & - & - & - & - \\
\hline B. uniformis & 3 & + & + & - & - \\
\hline B. uniformis & 1 & + & - & - & - \\
\hline B. uniformis & 2 & - & - & - & - \\
\hline B. vulgatus & 1 & + & + & - & - \\
\hline B. vulgatus & 6 & - & - & - & - \\
\hline B. vulgatus & 1 & - & - & 1 & 8.9 \\
\hline
\end{tabular}

ETBF: $B$. fragilis - enterotoxigenic

drate was able to inhibit the HA in the strain B. fragilis p3-3.

The $b f t$ gene was detected only in 13 cytotoxic strains and the enterotoxin production was confirmed by a morphologic alteration in the HT-29/C 1 cells. All the ETBF were isolated from diarrhea stools and they produced a characteristic 294-bp band by PCR, and a cytotoxic effect, which was visible after $4 \mathrm{~h}$, producing refringent-rounded cells with clear outlines and detached one from another.

The MIC values to antibiotics and metals for the 64 tested species are showed in Tables II and III, respectively. All the strains showed $100 \%$ of resistance to lead and nickel. Moreover, imipenem and metronidazole were very actives against all strains.

Plasmids of low molecular weight were observed in 3 enterotoxigenic $B$. fragilis $(4.4 \mathrm{~kb})$, in 1 non-enterotoxigenic $B$. fragilis $(4.4 \mathrm{~kb})$, in 1 non-enterotoxigenic $B$. fragilis (2.9 and $4.8 \mathrm{~kb}$ ) and in 1 B. vulgatus $(8.9 \mathrm{~kb})$ (Table I).

\section{DISCUSSION}

In this study, all the examined $B$. fragilis strains possessed a capsule, according to Kasper et al. (1977) and Domingues et al. (1995). The capsular polysaccharide $B$. fragilis acts as a protector against neutrophil phagocytes and the complement bactericidal activity; it can produce abscesses in animals (Lindberg \& Weintraub 1985). Moreover, all the tested strains showed characteristics such as $\beta$-hemolytic, hydrophilic, and human or horse serum resistant, in accordance with Rotimi and Eke (1984), Oyston and Handley (1990), and Namavar et al. (1991).

Bacterial capsules are usually hydrophilic, contributing, therefore, to the low hydrophobicity of the cellular 
TABLE II

Antimicrobial activity and resistance rates of 10 antibiotics to 64 bacteria of the Bacteroides fragilis group

\begin{tabular}{|c|c|c|c|c|c|}
\hline \multirow[b]{2}{*}{ Antibiotics } & \multirow{2}{*}{$\begin{array}{c}\text { Breakpoint }^{a} \\
\mu \mathrm{g} / \mathrm{ml}\end{array}$} & \multicolumn{3}{|c|}{$\mathrm{MIC}(\mu \mathrm{g} / \mathrm{ml})$} & \multirow{2}{*}{$\begin{array}{c}(\%) \\
\text { Resistance }\end{array}$} \\
\hline & & Range & $50 \%$ & $90 \%$ & \\
\hline Amoxicillin & 8 & -256 & 32 & 256 & 90.5 \\
\hline Amoxcillin/Clavulanic acid & 8 & $\leq 0.25-64$ & 8 & 32 & 40.5 \\
\hline Ampicillin & 4 & $\leq 0.25-256$ & 16 & 256 & 92 \\
\hline Cefoxitin & 16 & $\leq 0.25-256$ & 16 & 32 & 23.5 \\
\hline Clindamycin & 8 & $\leq 0.25-256$ & $\leq 0.25$ & 256 & 34.5 \\
\hline Erythromycin & 8 & $\leq 0.25-256$ & 256 & 256 & 97 \\
\hline Imipenem & 16 & $\leq 0.25$ & $\leq 0.25$ & $\leq 0.25$ & 0 \\
\hline Metronidazole & 16 & $\leq 0.25-4$ & $\leq 0.25$ & 2 & 0 \\
\hline Penicillin G & 8 & $1-256$ & 32 & 256 & 87.5 \\
\hline Tetracycline & 8 & $\leq 0.25-32$ & 16 & 16 & 51.5 \\
\hline
\end{tabular}

$a$ : breakpoints used from NCCLS (1997)

TABLE III

Antimicrobial activity and resistance rates of six metals to 64 bacteria of the Bacteroides fragilis group

\begin{tabular}{|c|c|c|c|c|}
\hline \multirow[b]{2}{*}{ Metals $^{a}$} & \multicolumn{3}{|c|}{$\mathrm{MIC}(\mu \mathrm{g} / \mathrm{ml})$} & \multirow{2}{*}{$\begin{array}{c}\% \\
\text { Resistance }\end{array}$} \\
\hline & Range & $50 \%$ & $90 \%$ & \\
\hline $\mathrm{HgCl}_{2}$ & $\leq 0.25-8$ & 4 & 8 & 59 \\
\hline $\mathrm{AgNO}_{3}$ & $\leq 0.25-32$ & 16 & 32 & 70 \\
\hline $\mathrm{CuSO}_{4}$ & $\leq 0.25-256$ & 16 & 64 & 68.5 \\
\hline $3 \mathrm{CdSO}_{4} \cdot 8 \mathrm{H}_{2} \mathrm{O}$ & $\leq 0.25-128$ & 16 & 128 & 68.5 \\
\hline $\mathrm{PbCl}_{2}$ & $64-\leq 512$ & 512 & $\leq 512$ & 100 \\
\hline $\mathrm{NiSO}_{4} \cdot 6 \mathrm{H}_{2} \mathrm{O}$ & $128-\leq 512$ & 512 & $\leq 512$ & 100 \\
\hline
\end{tabular}

$a$ : the breakpoint for all metals was $2 \mathrm{mg} / \mathrm{ml}$ (Avila-Campos et al. 1991). Susceptibility for $B$. fragilis ATCC 43858: $\mathrm{HgCl}_{2}, 4 \mu \mathrm{g} /$ $\mathrm{ml} ; \mathrm{AgNO}_{3} 8 \mu \mathrm{g} / \mathrm{ml} ; \mathrm{CuSO}_{4}, 32 \mu \mathrm{g} / \mathrm{ml} ; 3 \mathrm{CdSO}_{4} .8 \mathrm{H}_{2} \mathrm{O}, 16 \mu \mathrm{g} /$ $\mathrm{ml} ; \mathrm{PbCl}_{2}, \leq 512 \mu \mathrm{g} / \mathrm{ml}$ and $\mathrm{NiSO}_{4} \cdot 6 \mathrm{H}_{2} \mathrm{O}, \leq 512 \mu \mathrm{g} / \mathrm{ml}$. Susceptibility for $B$. fragilis GAI $97124: \mathrm{HgCl}_{2}, 4 \mu \mathrm{g} / \mathrm{ml} ; \mathrm{AgNO}_{3}$, $0.5 \mu \mathrm{g} / \mathrm{ml} ; \mathrm{CuSO}_{4}, 8 \mu \mathrm{g} / \mathrm{ml} ; 3 \mathrm{CdSO}_{4} .8 \mathrm{H}_{2} \mathrm{O}, \leq 0.25 \mu \mathrm{g} / \mathrm{ml} ; \mathrm{PbCl}_{2}$, $\leq 512 \mu \mathrm{g} / \mathrm{ml}$ and $\mathrm{NiSO}_{4} \cdot 6 \mathrm{H}_{2} \mathrm{O}, 256 \mu \mathrm{g} / \mathrm{ml}$

surface (Oyston \& Handley 1990). In our study, it was not observed any correlation between the presence of capsule and hydrophobicity.

The serum bactericidal activity is perhaps the most important host's resistance factor against the systemic bacterial invasion. Thus, the resistance of the $B$. fragilis strain against human or horse sera may explain its pathogenic potential in severe clinical infections (Rotimi \& Eke 1984). Namavar et al. (1991) showed that avirulent B. fagilis strains were more sensitive to serum than the virulent ones, indicating that the complement is crucial for killing of avirulent strains.

Therefore, the resistance at $60^{\circ} \mathrm{C}$, for $60 \mathrm{~min}$, observed in 12 tested strains, suggests an association with the presence of capsule. Four strains (B. uniformis p3-2; B. fragilis p3-3; B. fragilis $\mathrm{p} 76 \mathrm{a} ;$ B. fragilis $\mathrm{p} 76 \mathrm{~b}$ ) produced hemagglutination. Oyston and Handley (1990) detected different hemagglutination patterns among $B$. fragilis strains, and these differences were not observed in this study. There was not any correlation between capsulation (as seen with Hiss stain) and hemagglutination in accordance with Namavar et al. (1991). Moreover, D-mannose, D-galactose, D-arabinose or D-xylose was able to inhibit HA in these organisms.

Domingues et al. (1991) analyzed $31 \mathrm{~B}$. fragilis isolated from intestinal microbiota and other infections, and they observed that $84.2 \%$ of clinical strains were HA-positive. On the other hand, Oyston and Handley (1990) observed that one $B$. fragilis strain produced human or horse erythrocytes agglutination, and 13 strains hemagglutinated rabbit's erythrocytes. These conflictive data about HA in B. fragilis have been observed, however, it can be suggested that adhesins or outer membrane proteins could be responsible for hemagglutination (Vel et al. 1986, Oyston \& Handley 1990).

By PCR, 13 ETBF showed a 294-bp band and they also produced morphologic alterations in the HT-29/C 1 cells. PCR assay proved to be a good methodological choice in the detection of fragilysin, due to its speed and ease of reading. The evaluation of the enterotoxin activity by the HT-29/C 1 cells assay was successful. Studies have shown that ETBF were recovered in $3.1 \%$ from feces of immunodeficient children (Bressane et al. 2001) and in 2.1\% in children with diarrhea (Krzyzanowsky \& Avila-Campos 2003). Moreover, Cáceres et al. (2000) showed the presence of ETBF in $8.4 \%$ of Nicaraguan children.

This fragilysin produced rounded and refringent cells with clear outlines and they were detached one from another. In this study, all the 13 ETBF strains isolated from diarrhea stools produced a characteristic rounded of the HT29/C 1 cells. Moreover, studies in vivo have showed that ETBF produce an accumulation of sodium, chloride, albumen, and protein. Despite of this fact, ETBF strains have been considered as enteropathogens to children and adults in several countries (Pantosti et al. 1994, 1997). However, it seems to be too early to suggest that this protease is a determinant factor of the B. fragilis invasiveness, and more studies are needed, according to Ferreira et al. (1999).

The bacteria of the $B$. fragilis group have been studied due to their pathogenic character and their resistance 
to several antibiotics and heavy metals. All isolates were resistant to lead and nickel. Studies have documented an alarming and gradual increase of the resistance to several antimicrobials in anaerobes, particularly in Bacteroides species (Turner et al. 1995, Snydman et al. 1996). In Brazil, Avila-Campos et al. (1991), Carvalho et al. (1997), and Pestana et al. (1999) have analyzed the antimicrobial susceptibility of $B$. fragilis isolated from both human and Callithrix penicillata marmoset gastrointestinal tracts showing an increase of resistance to drugs.

Bacteria of the $B$. fragilis group have shown an interesting multiple resistance to metronidazole, imipenem, and amoxycillin/clavulanic acid (Turner et al. 1995). On the other hand, Bacteroides strains are $\beta$-lactamases producers, which are able to hydrolyze most of the $\beta$-lactam drugs.

Data regarding metal susceptibility in $B$. fragilis group bacteria are few. However, metal ions resistance in organisms has gradually increased due to the use of metals in industry, agriculture, hospitals, and medicines. Moreover, Riley and Mee (1982) and Avila-Campos et al. (1991) have verified the metal ion resistance in $B$. fragilis isolated from human infections.

None plasmid-positive strains (B. fragilis $\mathrm{p} 15 \mathrm{j}$ with plasmid of $4.4 \mathrm{~kb}, B$. vulgatus $23 \mathrm{j}$ with $8.9 \mathrm{~kb}, B$. fragilis p35a with 4.8 and $2.9 \mathrm{~kb}, B$. fragilis p35b with $4.4 \mathrm{~kb}, B$. fragilis p60c with $4.4 \mathrm{~kb}$ and $B$. fragilis p60h with $4.4 \mathrm{~kb}$ ) lost these elements after the EtBr treatment. Pestana et al. (1999) showed that from 5 B. fragilis strains, only 1 strain harbored plasmid, which was associated to the resistance to penicillin and clindamycin. However, several studies have shown that Bacteroides spp. contain transferable plasmids (Tally et al. 1979, Welch et al. 1981). Whether or not, the connection between the resistance to some heavy metals and the presence of plasmid in Bacteroides spp. remains to be investigated.

Plasmids of low molecular weight are often observed in many Bacteroides spp. recovered from infections or from the indigenous fecal microbiota (Beul et al. 1985). Wallace et al. (1981) showed that $25 \%$ of clinical Bacteroides isolates contained three different plasmids $(5,3$, and $2 \mathrm{MDa}$ ), and Soki et al. (1999) showed 5.5 and $4.2 \mathrm{~kb}$ plasmids among Bacteroides spp. isolated from both clinical isolates and fecal samples of healthy donors.

According to Wallace et al. (1981) the resistance to metal ions in Bacteroides spp. is intrinsic rather than plasmid borne. In this study, we observed plasmids with low weight. The occurrence of small cryptic plasmids with the same molecular size in different Bacteroides strains in different parts of the world may be due to their horizontal mobilization by several different conjugative elements which may promote their spread through the indigenous microbiota (Smith \& Parker 1996).

Species of the $B$. fragilis group are important organisms in the pathogenesis of clinical infections and a periodic evaluation of the virulence factors and antimicrobial susceptibility are suggested. Moreover, the wide distribution of plasmids may signal a potential problem if they acquire an antibiotic resistance or pathogenicity determinants, which may render the treatment of bacteroides infections more difficult.

\section{ACKNOWLEDGMENTS}

To Ms Zulmira Alves de Souza for her technical support.

\section{REFERENCES}

Avila-Campos MJ 1995. Haemolytic activity of Actinobacillus actinomycetemcomitans strains on different blood types. Rev Inst Med Trop 37: 215-217.

Avila-Campos MJ, Carvalho MAR, Damasceno CAV, ChartoneSouza E, Cisalpino EO 1991. Population stability in species of the Bacteroides fragilis group, under mercuric chloride action. Rev Microbiol 22: 93-96.

Beul HA, von Eicher-Streiber C, Schreiner M, Schwindling FP, Weinblum D, Zöllner EJ, Dierich M 1985. Characterization of cryptic plasmids in clinical isolates of Bacteroides fragilis. J Med Microbiol 20: 39-48.

Bressane MA, Durigon LE, Avila-Campos MJ 2001. Prevalence of the Bacteroides fragilis group and enterotoxenic Bacteroides fragilis in immunodeficient children. Anaerobe 7: 277-281.

Cáceres M, Zhang G, Weintraub A, Nord CE 2000. Prevalence and antimicrobial susceptibility of enterotoxigenic Bacteroides fragilis in children with diarrhea in Nicaragua. Anaerobe 6: 143-148.

Carvalho CB, Moreira JL, Ferreira MCS 1997. Survey of Bacteroides fragilis group susceptibility patterns in Brazil. Int J Antimicrob Agents 8: 115-120.

Domingues RMCP, Cavalcanti SMB, Fonseca MEF, Ferreira MCS 1991. Hemagglutination activity of Bacteroides fragilis as a virulence marker. Rev Microbiol 22: 277-281.

Domingues RMCP, Oliveira M, Hirata RJ, Andrade AFB, Ferreira MCS 1995. Bacteroides fragilis: an exogenous pathogen? Zbl Bakt 282: 296-302.

Duerden BI 1980. The isolation and identification of Bacteroides spp. from the normal human faecal flora. J Med Microbiol 13: 69-78.

Ferreira R, Alexandre MCF, Antunes ENF, Pinhão AT, Moraes SR, Ferreira MCS, Domingues RMCP 1999. Expression of Bacteroides fragilis virulence markers in vitro. J Med Microbiol 48: 999-1004.

Franco AA, Mundy LM, Trucksis M, Wu S, Kaper JB, Sears CL 1997. Cloning and characterization of the Bacteroides fragilis metalloprotease toxin gene. Infect Immun 65: 1007 1013.

Gorbach SL, Bartlett JG 1974. Anaerobic infections. N Engl J Med 290: 1177-1184.

Holdeman LV, Cato EP, Moore WE 1977. Anaerobic Laboratory Manual, 4th ed., Virginia Polytechnic Institute, Blackburg, VA.

Kasper DL, Hayes ME, Reinap BG, Craft FO, Onderdonk AB, Polk BF 1977. Isolation and identification of encapsulated strains of Bacteroides fragilis. J Infect Dis 136: 75-81.

Kato N, Liu CX, Kato H, Watanabe K, Tanaka Y, Yamamoto T, Suzuki K, Ueno K 2000. A new subtype of the metalloprotease toxin gene and the incidence of the three $b f t$ subtypes among Bacteroides fragilis isolates in Japan. FEMS Microbiol Letts 182: 171-176.

Koshy SS, Montrose MH, Sears CL 1996. Human intestinal epithelial cells swell and demonstrate actin rearrangement in response to the metalloprotease toxin of Bacteroides fragilis. Infect Immun 64: 5022-5028.

Krzyzanowsky F, Avila-Campos MJ 2003. Detection of nonenterotoxigenic and enterotoxigenic Bacteroides fragilis in stool samples from children in São Paulo, Brazil. Rev Inst Med Trop São Paulo 45: 225-227.

Lindberg AA, Weintraub A 1985. Encapsulation and protection against phagocytosis by Bacteroides fragilis. Scand J Infect Dis S46: 27-32. 
Moncrief JS, Obiso RJ, Barroso LA, Kling JJ, Wright RL, Van Tassel, RL, Lyerly DM, Wilkins TD 1995. The enterotoxin of Bacteroides fragilis is a metalloprotease. Infect Immun 63: 175-181.

Myers LL, Firehammer BD, Shoop DS, Border MM 1984. Bacteroides fragilis: a possible cause of acute diarrheal disease in newborn lambs. Infect Immun 44: 241-244.

Namavar F, Marian A, Verweij-Van Vught JJ, Maclaren DM 1991. A study of the candidate virulence factors of Bacteroides fragilis. J Gen Microbiol 137: 1431-1435.

NCCLS-1997. National Committee for Clinical Laboratory Standard Methods for Antimicrobial Susceptibility Testing of Anaerobic Bacteria, 4th ed. Approved Standard. NCCLS document M11-A4. National Committee for Clinical Laboratory Standards, Wayne, PA.

Oyston PC, Handley PS 1990. Surface structures, haemagglutination and cell surface hydrophobicity of Bacteroides fragilis strains. J Gen Microbiol 136: 941-948.

Pantosti A, Cerquetti M, Colangeli R, D’Ambrosio F 1994. Detection of intestinal and extra-intestinal strains of enterotoxigenic Bacteroides fragilis by HT-29 cytotoxicity assay. J Med Microbiol 41: 191-196.

Pantosti A, Malpeli M, Wilks M, Menozzi MG, D'Ambrosio F 1997. Detection of enterotoxigenic Bacteroides fragilis by PCR. J Clin Microbiol 35: 2482-2486.

Pestana ACNR, Diniz CG, Farias LM, Carvalho MAR 1999. Plasmid-related resistance to clindamycin and penicillin $\mathrm{G}$ in a Bacteroides vulgatus strain. Anaerobe 5: 447-449.

Riley TV, Mee BJ 1982. Susceptibility of Bacteroides spp. to heavy metals. Antimicrob Agents Chemother 22: 889-892.

Rosenberg M, Perry A, Bayer EA, Gutnick DL, Rosenberg M, Ofek I 1981. Adherence of Acinetobacter calcoaceticus RAG1 to human epithelial cells and to hexadecane. Infect Immun 33: 29-33.

Rotimi VO, Eke PI 1984. The bactericidal action of human serum on Bacteroides species. J Med Microbiol 18: 355363.

Smith JC, Parker AC 1996. A gene product related to Tral is required for the mobilization of Bacteroides mobilizable transposons and plasmids. Mol Microbiol 20: 741-750.

Snydman DR, McDermott L, Cuchural GL, Hecht DW, Iannini PB, Harrell LJ, Jenkins SG, O'Keefe JP, Pierson CL, Rihs JD, Yu VL, Finegold SM, Gorbach SL 1996. Analysis of trends in antimicrobial resistance patterns among clinical isolates of Bacteroides fragilis group species from 1990 to 1994. Clin Infect Dis 23 (Suppl. 1): S54-65.

Soki J, Szöke I, Nagy E 1999. Characterization of 5.5-kb cryptic plasmid present in different isolates of Bacteroides spp. originating from Hungary. J Med Microbiol 48: 25-31.

Sutter VL, Barry AL, Wilkins TD, Zabransky RL 1979. Collaborative evaluation of a proposed dilution method of susceptibility testing of anaerobic bacteria. Antimicrob Agents Chemother 16: 495-502.

Tally FP, Syndman DR, Gorbach SL, Malamy MH 1979. Plasmid-mediated transferable resistance to clindamycin and erythromycin in Bacteroides fragilis. J Infect Dis 139: 8388.

Turner P, Edwards R, Weston V, Gazis A, Ispahani P, Greenwood D 1995. Simultaneous resistance to metronidazole, co-amoxiclav, and imipenem in clinical isolates of B. fragilis. Lancet 345: 1275-1277.

Vel WAC, Navamar F, Marian A, Verweij-Van Vught JJ, Pubben ANB, Maclaren DM 1986. Haemagglutination by Bacteroides fragilis group. J Med Microbiol 21: 105-107.

Wallace BL, Bradley JE, Rogolsky M 1981. Plasmid analyses in clinical isolates of Bacteroides fragilis and other Bacteroides species. J Clin Microbiol 14: 383-388.

Welch RA, Jones KR, Macrina FL 1981. Transferable lincosamide-macrolide resistance in Bacteroides. Plasmid 2: 261268. 